\title{
IMPACT OF NITROGEN TOPDRESSING ON THE QUALITY PARAMETERS OF WINTER WHEAT (TRITICUM AESTIVUM L.) YIELD
}

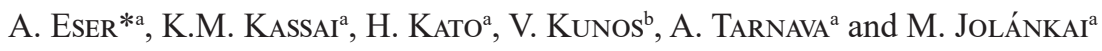 \\ ${ }^{a}$ Crop Production Institute, Szent István University, H-2100 Gödöllő, Páter Károly utca 1. Hungary \\ ${ }^{\mathrm{b}}$ Agricultural Institute, Centre for Agricultural Research, H-2462 Martonvásár, Brunszvik u. 2. Hungary
}

(Received: 18 November 2019; accepted: 5 April 2020)

\begin{abstract}
Scope of the study was to find more effective $\mathrm{N}$ fertilisation doses and applications to reach not only higher quantity but better quality grains as well as to be able to help preserving the continuity of feed and food quality improvement, since wheat is one of the most consumed crops all over the world.

Samples of winter wheat (Triticum aestivum L.) varieties harvested from the experimental field of the Szent István University in two consecutive crop seasons had been examined in the laboratory of the Crop Production Institute. Effects of nitrogen (N) application on the performance of grain protein were tested. Five high quality winter wheat varieties were studied regarding grain quality traits affected by applying undivided and split doses of $\mathrm{N}$. The evaluated samples show that increasing doses of $\mathrm{N}$ topdressing and increasing time of application have beneficial effects on the yield and the value of protein content. Wheat grain protein value ranged between $9.9 \%$ of the untreated Mv Karéj and Alföld, where the $120+40 \mathrm{~kg} \mathrm{ha}^{-1} \mathrm{~N}$ was applied resulting in the highest value of $16.0 \%$. Similarly, the gluten values among untreated and $\mathrm{N}$ applied plots were in a wide range. Mv Karéj had the lowest wheat gluten value on untreated plot with $18.4 \%$ and Alföld had the highest value with $36.8 \%$ on the plot where the $120+40 \mathrm{~kg} \mathrm{ha}^{-1} \mathrm{~N}$ was applied. There were no significant changes recorded on test weight and thousand kernel weight. In the case of baking quality, there were significant differences between varieties. The best records were obtained in the case of Mv Toborzó followed by Mv Karéj.
\end{abstract}

Keywords: grain protein, gluten, winter wheat, baking quality, nitrogen, nitrogen fertilisation

There are more lands planted with wheat in the world than with any other crop. It provides 20 percent of the world's caloric consumption, even 50 percent for the world's poorest, and it provides 20 percent of their protein consumption, too (WASHINGTON WheAT FACTS 2016/2017). The total global wheat output exceeded 749.3 million tons in 2016, according to FAOSTAT data (FAO, 2017). Wheat is also one of the most important cereals in Hungary and Turkey as well with a high economic value. The goal of wheat production is twofold: providing quantity and quality as well. Milling and baking qualities of wheat are mainly determined by the genetic basis; however, it can be influenced by management techniques as well (Pollhamer, 1981; Grimwade et al., 1996; Vida et al., 1996; Pepó, 2010). The determination of wheat milling quality is very complex, however, the quality measurements lean on the kernel hardness, protein, starch, internal insect infestation, colour, disease, size, and moisture parameters (POSNER, 2003). Baking quality of wheat flour is determined by grain protein concentration (GPC) and its composition, and is highly influenced by environmental factors such as nitrogen (N) fertilisation management (XUE, 2019). The protein content of wheat crops has important impacts on their nutritional quality for humans

* To whom correspondence should be addressed.

E-mail: adnaneser@hotmail.com 
and livestock and on their functional properties in food processing. (SHEWry \& HALFord, 2002). Economic value of winter wheat is affected by the genotype, cropping year, agroclimatic parameters as well as the agronomic applications and coordination (GYöRI, 2006; VÁRALLYAY, 2008). Nitrogen (N) is one of the macronutrients required for plant growth, with high effect on quality and quantity values of winter wheat. The quality of wheat varieties is strongly influenced by year and genotype effects, and the effects of the management systems are also determinative on some physical and gluten quality characters of the grain (RAKSZEGI et al., 2016). HoRvátr and co-workers (2014) also presented that increasing levels of N topdressing and increased number of applications had beneficial effects on the protein content as well as on wet gluten values of wheat grain. SzENTPÉTERY and co-workers (2005) found that increasing fertiliser dose applications had preferable effect on the protein and gluten contents, as well as quality improvement had been proved. KISMÁNYOKY and TóTH (2010) described that the increasing rate of $\mathrm{N}$ fertilisation application as well as the additional organic fertilisers influenced the biomass production and $\mathrm{N}$ uptake of winter wheat. The aim of the study was to investigate change in qualitative parameters of the winter wheat varieties sown in two crop seasons with different level and split/undivided doses application of nitrogen fertilisation.

\section{Materials and methods}

In years 2017 and 2018, a field trial of high milling and baking quality winter wheat (Triticum aestivum $\mathrm{L}$.) varieties were set up under identical agronomic conditions using split-plot design $\left(10 \mathrm{~m}^{2} / \mathrm{plot}\right)$. The trial was established at the experimental field of the Szent István University, Crop Production Institute, Hungary. Soil type of the experimental field was sand based brown forest soil (Chromic Luvisol). The textural classification of the soil was sandy loam with parameters shown in Table 1. The agronomic characteristic of the soil was neutral sandy soil with variable clay content. The soil structure was susceptible regarding compaction. The water retaining characteristics were poor due to the high sand fraction. The soil was exposed to drought impacts. The two-year experiment was set up in split-plot design with nine plot replications regarding each experimental factor such as variety and $\mathrm{N}$ application (time and dose) in each investigated year. The plots were sown and harvested with plot machines. Apart from $\mathrm{N}$ topdressing, all other agronomic treatments as well as sowing and harvesting were identically applied to all plots to study the impact of $\mathrm{N}$ treatments independently. $\mathrm{N}$ fertiliser topdressing was applied in single or split doses. $\mathrm{N}$ was applied in form of ammonium nitrate $\left(\mathrm{NH}_{4} \mathrm{NO}_{3}\right)$; the amounts are indicating the $\mathrm{N}$ content in this paper, not the molecule. $\mathrm{N}$ was investigated in 6 different variants: 4 levels single and 2 levels split dose treatments. Single application: $0,80,120$, and $160 \mathrm{~kg} \mathrm{ha}^{-1} \mathrm{~N}$, split doses application: $80+40 \mathrm{~kg} \mathrm{ha}^{-1}$ and $120+40 \mathrm{~kg} \mathrm{ha}^{-1}$ in two applications. Applications were done at tillering stage in the case of single application, while split dose treatment was applied at the stage of tillering and heading. There was no $\mathrm{N}$ application in autumn in any of the crop years. The present study examined the performance of five high baking quality winter wheat varieties Mv Karéj, Mv Nádor, Mv Toldi, Mv Toborzó, and Alföld. Grain yields of the winter wheat varieties were sampled and measured from each harvested plot. The protein, test weight, thousand grain weight, and baking quality parameters were measured from harvested wheat grain. Analyses were done at the research laboratory of the Szent Istvan University Crop Production Institute. Near infrared (NIR) spectroscopic equipment Mininfra Scan-T Plus 
2.02 version (ARANA, 2016) was used to measure gluten, protein, and Zeleny sedimentation values of whole grains. Falling number was also studied to determine amylase enzyme activity in the flour. The Hagberg Falling Number (HFN) Perten Type:1400 system, which meets the requirements of the AACC (American Association of Cereal Chemist) No.5681.04, ICC (International Cereal Chemist) No. 107/1, and PN EN ISO 3093:2010 standards, was used to determine the falling number. The OS 1 type equipment by the ISO 7971-3:2019 standard was used to measure test weight. Thousand grain weight and test weight were measured with the KERN EMS and the Sartorius MA-30 precision scales. Farinograph (Valorigraph) instrument had been used to describe baking quality of the dough. ANOVA module of the statistical software SPSS V.23 was used for the statistical analyses.

Table 1. Soil type of the experimental field at Szent István University, Crop Production Institute, Hungary

\begin{tabular}{cccccccc}
\hline & Humus $\%$ & $\mathrm{pH}\left(\mathrm{H}_{2} \mathrm{O}\right)$ & $\mathrm{K}_{\mathrm{A}}$ & Sand $\%$ & Silt $\%$ & Clay $\%$ & $\mathrm{CaCO}_{3}$ \\
\hline Medium & 1.32 & 7.08 & 40 & 49 & 25 & 26 & 0 \\
\hline
\end{tabular}

\section{Results and discussion}

Protein and gluten contents of the tested wheat grain samples indicate that $\mathrm{N}$ supply had high effect on examined varieties in accordance with earlier research results (PoLlHAMER, 1981; VIDA et al., 1996; PePó, 2010). There were varietal differences, too, as untreated plots had remarkable differences between varieties. Especially increasing dose applications had remarkable effect in the experimental year 2017.

One-way ANOVA test in Table 2 clarifies the results statistically; results are discussed case by case.

Table 2. Impact of undivided/split $\mathrm{N}$ topdressing applications on the quality parameters of wheat grain, 2017-2018 (Gödöllö, Hungary)

\begin{tabular}{|c|c|c|c|c|c|c|c|}
\hline \multicolumn{8}{|c|}{ ANOVA by treatments } \\
\hline Variety & & & Sum of squares & df & Mean square & $\mathrm{F}$ & Sig. \\
\hline \multirow[t]{13}{*}{ Alföld } & \multirow[t]{3}{*}{ Test_weight(hl) } & Between groups & 11.99 & 5.00 & 2.40 & 2.19 & 0.06 \\
\hline & & Within groups & 111.48 & 102.00 & 1.09 & & \\
\hline & & Total & 123.47 & 107.00 & & & \\
\hline & \multirow{3}{*}{$\begin{array}{l}\text { Thousand } \\
\text { kernel weight } \\
\text { (g) }\end{array}$} & Between groups & 27.95 & 5.00 & 5.59 & 0.51 & 0.77 \\
\hline & & Within groups & 1110.87 & 102.00 & 10.89 & & \\
\hline & & Total & 1138.83 & 107.00 & & & \\
\hline & \multicolumn{7}{|l|}{$\begin{array}{l}\text { ANOVA by } \\
\text { treatments }\end{array}$} \\
\hline & \multirow[t]{3}{*}{ Falling number } & Between groups & 160764.75 & 5.00 & 32152.95 & 2.22 & 0.06 \\
\hline & & Within groups & 1477427.35 & 102.00 & 14484.58 & & \\
\hline & & Total & 1638192.10 & 107.00 & & & \\
\hline & \multirow[t]{3}{*}{ Protein } & Between groups & 111.32 & 5.00 & 22.27 & 18.68 & 0.00 \\
\hline & & Within groups & 121.56 & 102.00 & 1.19 & & \\
\hline & & Total & 232.88 & 107.00 & & & \\
\hline
\end{tabular}




\begin{tabular}{|c|c|c|c|c|c|c|c|}
\hline \multicolumn{8}{|c|}{ ANOVA by treatments } \\
\hline Variety & & & Sum of squares & $\mathrm{df}$ & Mean square & $\mathrm{F}$ & Sig. \\
\hline & Gluten & Between groups & 987.88 & 5.00 & 197.58 & 21.08 & 0.00 \\
\hline & & Within groups & 955.81 & 102.00 & 9.37 & & \\
\hline & & Total & 1943.69 & 107.00 & & & \\
\hline & Zeleny & Between groups & 3659.71 & 5.00 & 731.94 & 9.53 & 0.00 \\
\hline & & Within groups & 7835.60 & 102.00 & 76.82 & & \\
\hline & & Total & 11495.31 & 107.00 & & & \\
\hline & Baking quality & Between groups & 2172.55 & 5.00 & 434.51 & 3.39 & 0.01 \\
\hline & & Within groups & 13089.52 & 102.00 & 128.33 & & \\
\hline & & Total & 15262.07 & 107.00 & & & \\
\hline \multirow[t]{13}{*}{ MV Nádor } & $\begin{array}{l}\text { Test_weight } \\
\text { (hl) }\end{array}$ & Between groups & 9.56 & 5.00 & 1.91 & 1.50 & 0.20 \\
\hline & & Within groups & 129.75 & 102.00 & 1.27 & & \\
\hline & & Total & 139.31 & 107.00 & & & \\
\hline & $\begin{array}{l}\text { Thousand } \\
\text { kernel weight } \\
\text { (g) }\end{array}$ & Between groups & 138.84 & 5.00 & 27.77 & 6.24 & 0.00 \\
\hline & & Within groups & 453.60 & 102.00 & 4.45 & & \\
\hline & & Total & 592.44 & 107.00 & & & \\
\hline & Falling_number & Between groups & 5606.26 & 5.00 & 1121.25 & 0.10 & 0.99 \\
\hline & & Within groups & 1206753.40 & 102.00 & 11830.92 & & \\
\hline & & Total & 1212359.67 & 107.00 & & & \\
\hline & Protein & Between groups & 65.11 & 5.00 & 13.02 & 16.21 & 0.00 \\
\hline & & Within groups & 81.94 & 102.00 & 0.80 & & \\
\hline & & Total & 147.05 & 107.00 & & & \\
\hline & Gluten & Between groups & 592.99 & 5.00 & 118.60 & 15.69 & 0.00 \\
\hline
\end{tabular}

ANOVA by treatments

\begin{tabular}{llccccc}
\multirow{5}{*}{ Zeleny } & Within groups & 771.18 & 102.00 & 7.56 & & \\
& Total & 1364.17 & 107.00 & & & \\
& Between groups & 2374.65 & 5.00 & 474.93 & 9.76 & 0.00 \\
& Within groups & 4962.07 & 102.00 & 48.65 & & \\
& Total & 7336.72 & 107.00 & & & \\
Baking quality & Between groups & 164.97 & 5.00 & 32.99 & 2.28 & 0.06 \\
& Within groups & 694.98 & 48.00 & 14.48 & & \\
& Total & 859.95 & 53.00 & & &
\end{tabular}




\begin{tabular}{|c|c|c|c|c|c|c|c|}
\hline \multicolumn{8}{|c|}{ ANOVA by treatments } \\
\hline Variety & & & Sum of squares & df & Mean square & $\mathrm{F}$ & Sig. \\
\hline \multirow[t]{21}{*}{ MV Karéj } & $\begin{array}{l}\text { Test_weight } \\
\text { (hl) }\end{array}$ & Between groups & 3.23 & 5.00 & 0.65 & 0.13 & 0.99 \\
\hline & & Within groups & 521.60 & 102.00 & 5.11 & & \\
\hline & & Total & 524.83 & 107.00 & & & \\
\hline & Thousand & Between groups & 81.70 & 5.00 & 16.34 & 1.34 & 0.26 \\
\hline & & Within groups & 1246.45 & 102.00 & 12.22 & & \\
\hline & & Total & 1328.14 & 107.00 & & & \\
\hline & Falling_number & Between groups & 44637.32 & 5.00 & 8927.46 & 1.81 & 0.12 \\
\hline & & Within groups & 502698.59 & 102.00 & 4928.42 & & \\
\hline & & Total & 547335.91 & 107.00 & & & \\
\hline & Protein & Between groups & 121.32 & 5.00 & 24.27 & 13.86 & 0.00 \\
\hline & & Within groups & 178.56 & 102.00 & 1.75 & & \\
\hline & & Total & 299.88 & 107.00 & & & \\
\hline & Gluten & Between groups & 1279.15 & 5.00 & 255.83 & 19.90 & 0.00 \\
\hline & & Within groups & 1311.16 & 102.00 & 12.86 & & \\
\hline & & Total & 2590.31 & 107.00 & & & \\
\hline & Zeleny & Between groups & 6202.36 & 5.00 & 1240.47 & 22.89 & 0.00 \\
\hline & & Within groups & 5526.90 & 102.00 & 54.19 & & \\
\hline & & Total & 11729.25 & 107.00 & & & \\
\hline & Baking quality & Between groups & 2683.40 & 5.00 & 536.68 & 19.01 & 0.00 \\
\hline & & Within groups & 2879.56 & 102.00 & 28.23 & & \\
\hline & & Total & 5562.96 & 107.00 & & & \\
\hline \multicolumn{8}{|l|}{$\begin{array}{l}\text { ANOVA by } \\
\text { treatments }\end{array}$} \\
\hline \multirow[t]{10}{*}{ MV Toborzó } & Test_weight & Between groups & 2.11 & 5.00 & 0.42 & 0.08 & 1.00 \\
\hline & & Within groups & 529.54 & 102.00 & 5.19 & & \\
\hline & & Total & 531.64 & 107.00 & & & \\
\hline & Thousand & Between groups & 131.00 & 5.00 & 26.20 & 1.05 & 0.39 \\
\hline & & Within groups & 2551.08 & 102.00 & 25.01 & & \\
\hline & & Total & 2682.08 & 107.00 & & & \\
\hline & Falling_number & Between groups & 33203.60 & 5.00 & 6640.72 & 0.49 & 0.78 \\
\hline & & Within groups & 1374205.67 & 102.00 & 13472.61 & & \\
\hline & & Total & 1407409.27 & 107.00 & & & \\
\hline & Protein & Between groups & 75.83 & 5.00 & 15.17 & 6.57 & 0.00 \\
\hline
\end{tabular}




\begin{tabular}{|c|c|c|c|c|c|c|c|}
\hline \multicolumn{8}{|c|}{ ANOVA by treatments } \\
\hline Variety & & & Sum of squares & $\mathrm{df}$ & Mean square & $\mathrm{F}$ & Sig. \\
\hline & & Within groups & 235.31 & 102.00 & 2.31 & & \\
\hline & & Total & 311.13 & 107.00 & & & \\
\hline & Gluten & Between groups & 797.88 & 5.00 & 159.58 & 9.94 & 0.00 \\
\hline & & Within groups & 1636.83 & 102.00 & 16.05 & & \\
\hline & & Total & 2434.71 & 107.00 & & & \\
\hline & Zeleny & Between groups & 3676.52 & 5.00 & 735.30 & 22.67 & 0.00 \\
\hline & & Within groups & 3309.08 & 102.00 & 32.44 & & \\
\hline & & Total & 6985.59 & 107.00 & & & \\
\hline & Baking quality & Between groups & 800.27 & 5.00 & 160.06 & 0.97 & 0.44 \\
\hline & & Within groups & 16871.26 & 102.00 & 165.40 & & \\
\hline & & Total & 17671.53 & 107.00 & & & \\
\hline \multirow[t]{7}{*}{ MV Toldi } & $\begin{array}{l}\text { Test_weight } \\
\text { (hl) }\end{array}$ & Between groups & 20.70 & 5.00 & 4.14 & 0.70 & 0.62 \\
\hline & & Within groups & 601.57 & 102.00 & 5.90 & & \\
\hline & & Total & 622.28 & 107.00 & & & \\
\hline & $\begin{array}{l}\text { Thousand } \\
\text { kernel weight } \\
\text { (g) }\end{array}$ & Between groups & 93.38 & 5.00 & 18.68 & 3.69 & 0.00 \\
\hline & & Within groups & 515.92 & 102.00 & 5.06 & & \\
\hline & & Total & 609.29 & 107.00 & & & \\
\hline & Falling_number & Between groups & 26999.59 & 5.00 & 5399.92 & 0.15 & 0.98 \\
\hline
\end{tabular}

ANOVA by treatments

\begin{tabular}{llccccc}
\multirow{5}{*}{ Protein } & Within groups & 3624628.16 & 102.00 & 35535.57 & & \\
& Total & 3651627.75 & 107.00 & & & \\
& Between groups & 53.59 & 5.00 & 10.72 & 8.85 & 0.00 \\
& Within groups & 123.57 & 102.00 & 1.21 & & \\
Gluten & Total & 177.16 & 107.00 & & & \\
& Between groups & 545.28 & 5.00 & 109.06 & 7.55 & 0.00 \\
& Within groups & 1473.79 & 102.00 & 14.45 & & \\
\multirow{3}{*}{ Zeleny } & Total & 2019.07 & 107.00 & & & \\
& Between groups & 3088.55 & 5.00 & 617.71 & 10.29 & 0.00 \\
& Within groups & 6123.85 & 102.00 & 60.04 & & \\
Baking quality & Botal & 9212.40 & 107.00 & & & \\
& Between groups & 753.61 & 5.00 & 150.72 & 0.46 & 0.81 \\
& Within groups & 33358.66 & 102.00 & 327.05 & & \\
& Total & 34112.27 & 107.00 & & & \\
\hline
\end{tabular}


Table 3. Impact of $\mathrm{N}$ topdressing applications on wheat grain test weight. 2017-2018 (Gödöllö, Hungary)

\begin{tabular}{lccccc}
\hline \multicolumn{7}{c}{ Test weight $\left(\mathrm{kg} \mathrm{hl}^{-1}\right)$} \\
\hline $0+$ & Alföld & MV Nádor & MV Karéj & MV Toborzó & MV Toldi \\
$80+$ & 79.15 & 75.79 & 75.57 & 76.47 & 77.97 \\
$80+40$ & 79.17 & 74.95 & 75.68 & 76.19 & 77.29 \\
$120+$ & 78.86 & 75.13 & 77.03 & 76.49 & 77.50 \\
$120+40$ & 78.54 & 75.13 & 75.39 & 76.37 & 76.81 \\
$160+$ & 79.20 & 75.36 & 75.84 & 76.59 & 76.83 \\
\hline
\end{tabular}

Table 3 gives information on $\mathrm{N}$ application effects on test weight at the studied winter wheat varieties. Test weight $\left(\mathrm{kg} \mathrm{hl}^{-1}\right)$ values slightly decreased in some of the tested varieties by the increasing level of undivided $\mathrm{N}$ application, but the changes found were not significant. In addition, positive effect of split dose treatment had been detected, except in case of $\mathrm{Mv}$ Nádor $80+40 \mathrm{~kg} \mathrm{ha}^{-1}$ to $120 \mathrm{~kg} \mathrm{ha}^{-1} \mathrm{~N}$ application. The highest result had been recorded for the Alföld $120+40 \mathrm{~kg} \mathrm{ha}^{-1}$ split dose application with $79.2 \mathrm{~kg} \mathrm{hl}^{-1}$ and the lowest for Nador as $74.9 \mathrm{~kg} \mathrm{hl}^{-1}$. However, split dose $\mathrm{N}$ application did not present significant changes among the tested winter wheat varieties, similar results were reported by POLLHAMER (1981) and HORváTH and co-workers (2014).

Table 4 gives the results of the thousand kernel weight values with the effect of undivided/ split dose of $\mathrm{N}$ supply. Thousand kernel weight value decreased slightly in most of the cases for the increeasing undivided/split level of $\mathrm{N}$ applications, however, increasing number of $\mathrm{N}$ treatments had better effect in the comparison of $80+40 \mathrm{~kg} \mathrm{ha}^{-1}$ to $120 \mathrm{~kg} \mathrm{ha}^{-1}$ and $120+40$ $\mathrm{kg} \mathrm{ha}^{-1}$ to $160 \mathrm{~kg} \mathrm{ha}^{-1}$, except Mv Toborzó comparison of $120+40 \mathrm{~kg} \mathrm{ha}^{-1}$ to $160 \mathrm{~kg} \mathrm{ha}^{-1}$. Mv Nádor and Mv Toldi showed significant differences by the one-way ANOVA test of thousand kernel weight. Similar results were reported by SZENTPÉTERY and co-workers (2005) and HoRváTH and co-workers (2014). The highest thousand grain weight was recorded on the untreated Karéj plot with $46.7 \mathrm{~g}$ /thousand kernel weight, and the lowest was detected on an Alföld plot treated with undivided $160 \mathrm{~kg} \mathrm{ha}^{-1} \mathrm{~N}$ application resulting $38.0 \mathrm{~g}$ /thousand kernel weight.

Table 4. Impact of $\mathrm{N}$ topdressing applications on thousand kernel weight of wheat varieties. 2017-2018 (Gödöllö, Hungary)

\begin{tabular}{|c|c|c|c|c|c|}
\hline \multirow[t]{2}{*}{$\mathrm{N}$ topdressing } & \multicolumn{5}{|c|}{ Thousand kernel weight (g/1000 kernel) } \\
\hline & Alföld & MV Nádor & MV Karéj & MV Toborzó & MV Toldi \\
\hline $0+$ & 39.73 & 44.78 & 46.70 & 45.05 & 45.81 \\
\hline $80+$ & 38.73 & 43.16 & 45.58 & 42.64 & 44.20 \\
\hline $80+40$ & 38.63 & 42.79 & 45.82 & 42.42 & 45.07 \\
\hline $120+$ & 38.56 & 42.10 & 45.40 & 41.44 & 43.77 \\
\hline $120+40$ & 38.83 & 42.21 & 45.36 & 42.40 & 44.40 \\
\hline $160+$ & 38.02 & 41.09 & 43.78 & 42.60 & 42.88 \\
\hline
\end{tabular}

Based on the results of the experiment, it can be stated that increasing levels of $\mathrm{N}$ topdressing had significant effect on grain protein content in all studied winter wheat varieties, either in split or undivided dose applications. Figure 1 and Table 2 show the grain protein 
values in 2017-2018. Protein amounts changed from 9.9\% to $16.0 \%$. Highest value was observed on the Alföld plot with split $120+40 \mathrm{~kg} \mathrm{ha}^{-1} \mathrm{~N}$ application (16.0\%), and the lowest, 9.9\%, was obtained on Karéj untreated plot. Split dose application did not have significant effect compared to the same amount of undivided application.

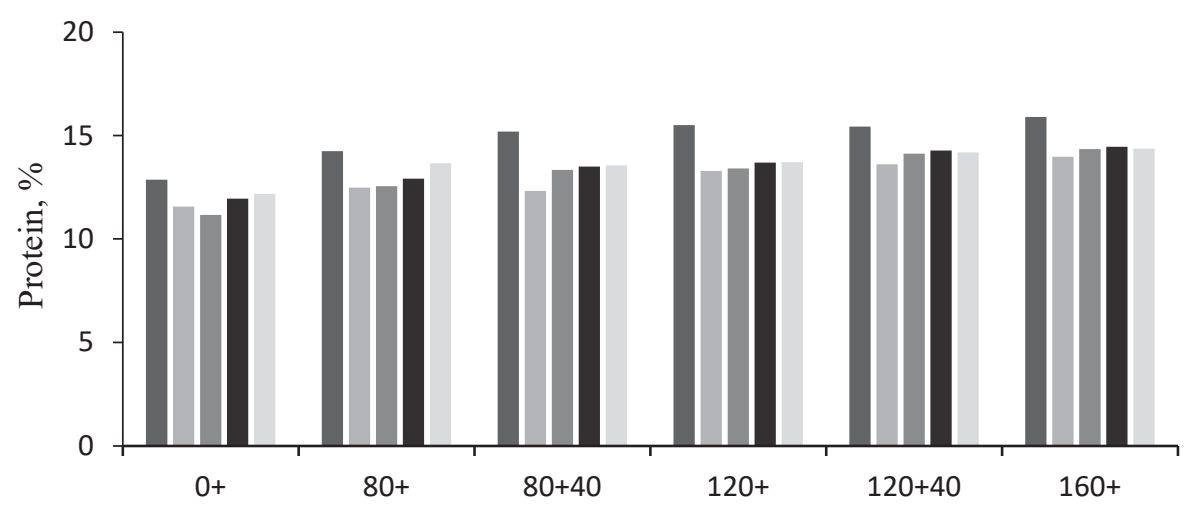

Fig. 1. Impact of $\mathrm{N}$ topdressing applications on wheat grain protein content, 2017-2018 (Gödöllö, Hungary) ㄸ: Alföld; ㅍ: MV Nádor; ㅌ: MV Karéj; ㅁ: MV Toborzó; : : MV Toldi

Gluten content was significantly affected by increasing doses of $\mathrm{N}$ applications as well with increased split dose applications. Similar examples have been reported by several authors (GYőri, 2006; KISMÁNYOKY \& TóTH, 2010; RAKsZEGi et al., 2016). Figure 2 and Table 2 show strong effect of $\mathrm{N}$ application on grain gluten content regardless of crop year, variety, or split/undivided application. Among the evaluated samples, the Alföld plot had the highest value $(36.8 \%)$, where $120+40 \mathrm{~kg} \mathrm{ha}^{-1}$ split $\mathrm{N}$ doses had been applied. In addition, Karéj had the lowest value with $18.4 \%$ on the untreated plot, and split dose application did not have significant effect on gluten content compared to the same amount of undivided application.

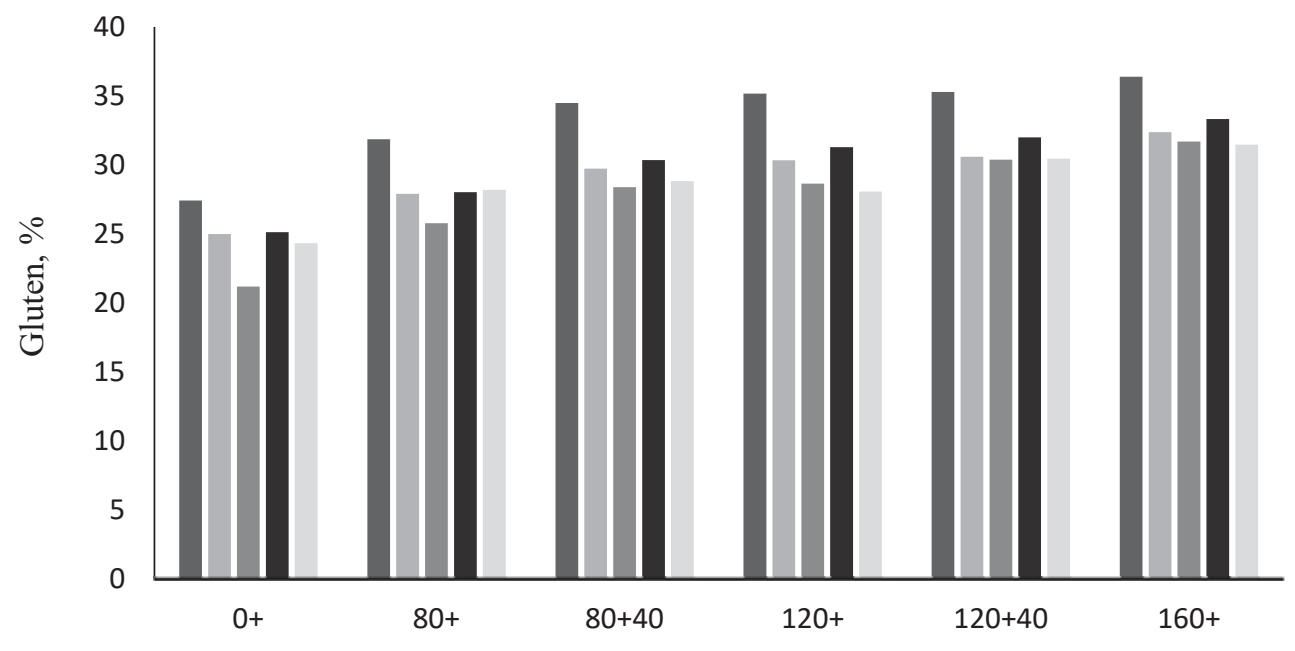

Fig. 2. Impact of $\mathrm{N}$ topdressing applications on wheat grain gluten content, 2017-2018 (Gödöllö. Hungary) ㅁ: Alföld; :: MV Nádor; ㅍ: MV Karéj; ㅁ: MV Toborzó; : : MV Toldi 
The results obtained show that all increasing levels of $\mathrm{N}$ applications affected the baking quality of the investigated winter wheat varieties, in accordance with the findings of earlier research results (SHEwry \& HALFORD, 2002; GYŐRI, 2006; PePÓ, 2010), shown in Figure 3. The lowest value, 53, was recorded in the case of Alföld on the untreated plot, and the best value, 100, was found for Toborzó on the $120+40 \mathrm{~kg} \mathrm{ha}^{-1}$ split dose $\mathrm{N}$ applied plot. As well as increasing levels of $\mathrm{N}$ fertilisation, increasing number of the applications also had positive impact on baking quality of tested winter wheat varieties. Varieties Alföld and Karéj demonstrated significant differences, and the split application of $80+40$ and $120+40 \mathrm{~kg} \mathrm{ha}^{-1}$ resulted $2.9 \%$ better values compared to 120 and $160 \mathrm{~kg} \mathrm{ha}^{-1}$ single applications. $\mathrm{N}$ addition had no significant effect on falling number (Table 2), however, Zeleny sedimentation number increased with increasing doses of $\mathrm{N}$ regardless of the variety.

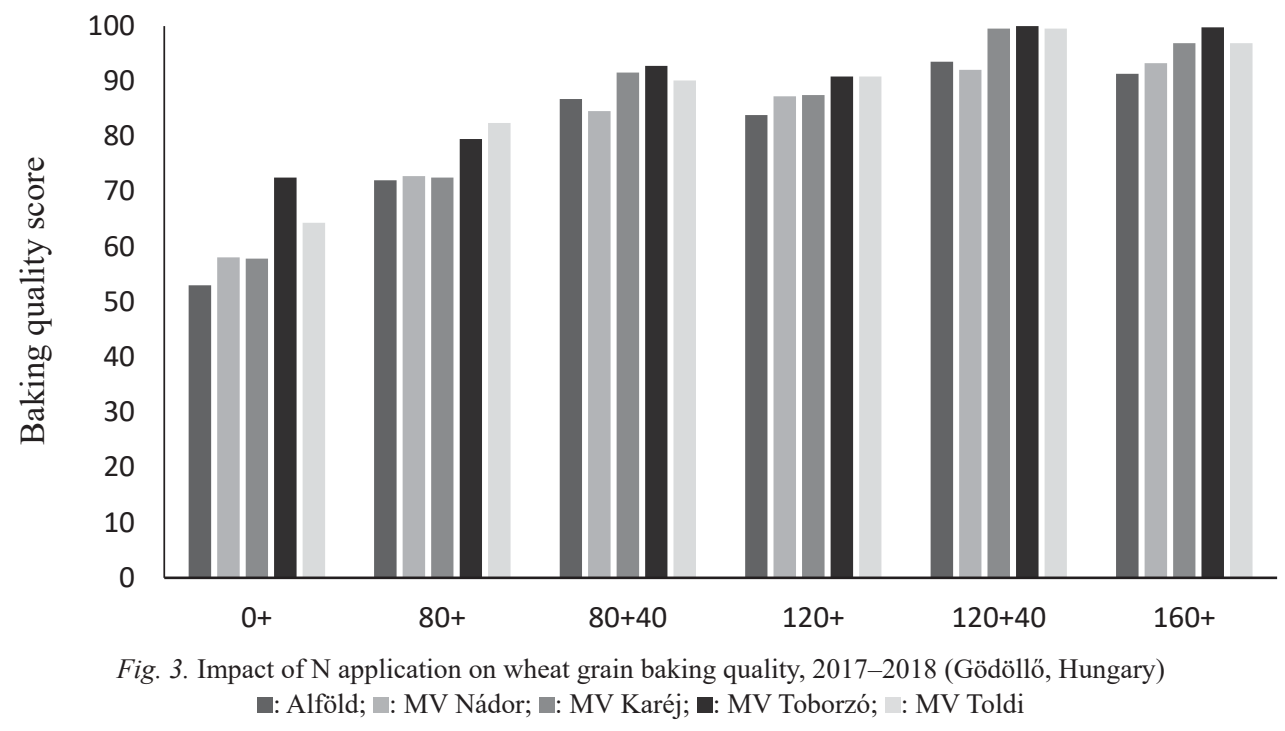

\section{Conclusions}

Rising amounts of $\mathrm{N}$ topdressing and the increased number of fertiliser applications were proved to have favourable impact on the crop yield and quality, on the amount of protein content, as well as on gluten values of tested winter wheat varieties. There were differences between the protein and quality results of the two cropping seasons due to meteorological differences; however, all parameters of the experimental agronomic techniques applied and all 5 wheat varieties used for both cropping seasons were identical. Among the investigated varieties, Alföld had the highest protein and gluten contents, and Mv Toborzó had the best baking quality among the tested varieties. Increasing doses of $\mathrm{N}$ application had significant effect on Zeleny sedimentation number, but no effect of split application was detected. $\mathrm{N}$ treatment had no significant effect on falling number. Increasing doses of $\mathrm{N}$ treatment had no significant effect on test weight, but split application gave better results compared to single treatment with the same dosage.

The authors are grateful for the financial support of the Tempus Public Foundation and NVKI of the Government of Hungary. 


\section{References}

AACC (2010): Approved methods of analysis $11^{\text {th }}$ ed. Determination of Falling Number Method No. 56-81.04.

Arana, I. (ED.) (2016): Physical properties of foods: Novel measurement techniques and applications. CRC Press, 420 pages.

FAO (2017): Food and Agriculture Organization of the United Nations, Land Resources. FAOSTATS-Crops. http://faostat.fao.org/site/567/default.aspx\#ancor (last accessed: 10. October 2019).

Grimwade, B., Tatham, A.S., Freedman, R.B., Shewry, P.R. \& Napier, J.A. (1996): Comparison of the expression patterns of wheat gluten proteins and proteins involved in the secretory pathway in developing caryopses of wheat. Plant Mol. Biol., 30, 1067-1073.

GyöRI, Z. (2006): A trágyázás hatása az őszi búza minőségére (Impacts of fertilizer application on winter wheat quality). Agrofórum, 17(9), 14-16.

Horváth, Cs., Kis, J., Tarnawa, Á., Kassai, K., Nyárai, H. \& JolánKaI, M. (2014): The effect of nitrogen fertilization and crop year precipitation on the protein and wet gluten content of wheat (Triticum aestivum L.) grain. Agrokem. Talajtan, 63(1),159-164.

ICC (1995): Determination of the Falling Number according to Hagberg - as a measure of the degree of alphaamylase activity in grain and flour. Method No. 107/1

ISO (2019): Cereals - Determination of bulk density, called mass per hectoliter. ISO 7971-3:2019

KismányoKy, T. \& TóTH, Z. (2010): Effect of mineral and organic fertilization on soil fertility as well as on the biomass production and $\mathrm{N}$ utilization of winter wheat (Triticum aestivum L.) in a long-term cereal crop rotation experiment (IOSDV). Arch. Acker. Pfl. Boden., 56(4), 473-479.

PePó, P. (2010): Adaptive capacity of wheat (Triticum aestivum L.) and maize (Zea mays L.) crop models to ecological conditions. Növénytermelés, 59. Suppl., 325-328.

PN EN ISO (2010): Wheat, rye and their flours, durum wheat and durum wheat semolina - Determination of the falling number according to Hagberg-Perten. PN EN ISO 3093:2010

Pollhamer, E. (1981): A búza és a liszt minősége. (Quality of wheat and flour). Mezőgazdasági Kiadó. Budapest. 203 pages.

Posner, E.S. (2003): Principles of milling. Encyclopedia of food science, food technology and nutrition. Academic Press, Harcourt Brace Jovanovich Publishers. London, pp. 3980-3986.

Rakszegi, M., Mikó, P., Löschenberger, F., Hiltbrunner, J., Aebi, R. ... \& Bedö, Z. (2016): Comparison of quality parameters of wheat varieties with different breeding origin under organic and low-input conventional conditions. J. Cereal Sci., 69.297-305.

Shewry, P. \& HALFORD, N. (2002): Cereal seed storage proteins: structures, properties and role in grain utilization. J. Exp. Bot., 53(370), 947-958.

Szentpétery, Zs., Kleinheincz, Cs., SzÖllösi, G. \& JolánKaI, M. (2005): Effect of nitrogen top-dressing on winter wheat yield, quality and quantity. Acta Alimentaria, 34, 177-185.

VÁRAllyay, G. (2008): Extreme soil moisture regime as limiting factor of the plants' water uptake. Cereal Res. Commun., 36(2), 3-6.

VIDA, GY., BEDő, Z. \& JolÁNKAI, M. (1996): Agronómiai kezeléskombinációk őszi búzafajták sütőipari minőségére gyakorolt hatásának elemzése fökomponens-analízissel (Investigation of the effect of agronomical treatment combinations on the winter wheat's baking qualities with main component analysis). Növénytermelés, 45(6), $453-462$.

WASHINGTON WHEAT FACTS 2016/2017: Washington Grain Commission http://wagrains.org/wp-content/ uploads/2015/04/WGC-2016-17WF4WebFinal.pdf (last accessed: 10 October 2019).

Xue, C., Matros, A., Mock, H.-P. \& Mühling, K.-H. (2019): Protein composition and baking quality of wheat flour as affected by split nitrogen application. Front. Plant Sci., 10, 642.

Open Access statement. This is an open-access article distributed under the terms of the Creative Commons Attribution 4.0 International License (https://creativecommons.org/licenses/by/4.0/), which permits unrestricted use, distribution, and reproduction in any medium, provided the original author and source are credited, a link to the CC License is provided, and changes - if any - are indicated. (SID_1) 